Plant and Soil 86, 113-125 (1985).

Ms. 6074

- 1985 Martinus Nihoff/Dr W. Junk Publishers, Dordrecht. Printed in the Netherlands.

\title{
Genotype dependent variation in mycorrhizal colonization and response to inoculation of pearl millet
}

\author{
K. R. KRISHNA, K. G. SHETTY, P. J. DART* and D, J, ANDREWS** \\ International Crop Research Instirute for the Semi.Arid Tropics, Patancheru 502.324, \\ Andhre Pradesh. India
}

Received 30 August 1984. Accepted December 1984

Key words Genetic crosses Genotypes Mycorrhizal colonization Pearl millet

Plant effects Response

Summary Genotypes of pearl millet (Pennisetum americanum L. Leeke) were examined for differences in vesicular-arbuscular mycorrhizal (VAM) colonization and response to inoculation. For thirty genotypes tested across three field locations there was a range of mycorrhizal colonization intensity between 25 and $56 \%$. In another experiment with two male-sterile lines, restoret lines and theis derived crosses, grown in pots fllled with non-sterilized soll there were significant differences between genotypes for colonization by mycorrhiza. This showed hostgenotype dependence for mycorthizal colonization.

Root growth rates, mycorrhizal root length, percentage root colonization and plant growth and $P$ uptake were studied in ten genotypes. A set of 3 genotypes with similar root lengths varied significantly with regard to mycorrhizal root length and the percentage colonization. This supports the suggestion that VAM colonization and spread is dependent on the host genotype. The growth responses differed significantly between the genotypes and they also differed in theit responses to $P$ uptake and VAM inoculation. The utility of host-genotype dependent differences in VAM symbiosis in plant breeding is discussed.

\section{Introduction}

Plant growth response (efficiency) to mycorrhizal symbiosis depends on three major components, the plant, the mycorrhizal fungus and the soil environment. An improvement in this efficiency can be made by manipulating any of these three components. Many workers have attempted to identify and select mycorrhizal fungi with improved performance in particular environments ${ }^{14}$. For example, Carling and Brown ${ }^{3}$ screened various fungal isolates under low and high soil fertility regimes. Soil factors affecting mycorrhizae fungi have also been examined $^{11}$, but there is little work on plant dependent variation in mycorrhizal symbiosis.

An essential requirement for good host plant response to mycorrhiza is a rapid colonization of roots during the early growth stages of the

- Research School of Biological Sciences, Australian National University, Canberra City, P.O. Box 475, ACT 2601, Australia.

** Department of Agronomy, University of Nebraska, Lincoin, Nebraska 68588, USA. Journal Article No. 453 
host plant. Mosse" describes variation in colonization between plant species: some were colonized freely, while certain grasses rarely showed $50 \%$ colonization. Powell and Sithamparanathan ${ }^{19}$ found that when legumes and grasses were inoculated under similar conditions, with three separate VAM fungal species, the legumes averaged $67 \%$ root colonization but the grass species had only $30 \%$. There could also be differences in VAM colonization between cultivars of the same crop species ${ }^{2}$

(ienotype dependent variation in nutrient uptake, for example phosphorus". has been well documented'. (ertain genotypes of sorghum are adapted better than others to $P$ deficient conditions and are ef ficient in the uptake of this element. Reports on genotype differences in P uptake have not examined the VAM status of the plants. It is possible that such adaptations to nutrient stress are mediated hy mycorrhiza. Since myeorrhiza are considered to play a role in $\mathrm{P}$ uptake. it would he reasonable to expect that genotype differences for my. corrhizal symbiosis and responses might also exist. In this paper we examine the root colonization of several pearl millet genotypes for differences in the extent of root colonization, and plant growth and $P$ uptake response in the glasshouse and field.

\section{Materials and methods}

\section{Firld trials}

In order to caamine if VAM colonization was hos dependent, thirty genotypes of pearl millet were tested across thee Allisol field kewtions (A. B and (C) at the IC RISAT (emer in India. All sites carried a natural population of lour mycorrhiza geners (filomus, cipasporo. Acaulospura and Sclerocystis (Table I).

The first trial (Alfisol A) was conducted during the rainy season (June to Octuber) of 1982 with no irrigation and the other two during the summer (Jan to May) of 1983 with furtow irrigation as required. The experimental area was divided into 4 blocks of 30 plots each of two $3 \mathrm{~m}$ rows. spased $75 \mathrm{~cm}^{2}$ apart. Treatments (genotypes) were arranged in a randomized block design. Seeds were hand sown 3-5 seeds per hill with a distance of $10 \mathrm{~cm}$ between hills. Thinning to one plant per hill was carried out 21 days after planting. Urea at the rate of $20 \mathrm{~kg} \mathrm{~N} / \mathrm{ha}$ was top dressed as a hand placement 25 days after emergence for all trials. Roots were sampled at 60 days after planting. Five plants were selected and the shoot portion was cut off at the collar zone close to the soil surface. Roots from each plant were carefully dup up to a depth of $30 \mathrm{~cm}$ taking eare to avoid roots from the nejghbuuring plants. Sampled roots were placed in plastic bags and taken to the laboratory. where they were cut to $3 \mathrm{~cm}$ lengths and mixed thoroughly. Four random sub-samples $(2-3 \mathrm{~g}$ fresh sample $)$ for each plant were transferred into $30 \mathrm{ml}$ screwcap Bijou hottles and processed for the determination of percentage colonization ${ }^{18}$.

\section{Pot trials}

(icneral meshod. The VAM fungus Gigaspora calospora Nicol. and Gerd. was maintained on Cenchrus ciliaris L. Link., a perennial host, grown in a sterilized sand:alfisol soil mixture $(1: 1 \mathrm{v} / \mathrm{v})$ for a minimum period of 90 days. For VAM inoculation. $50 \mathrm{ml}$ sand : soil mixture containing ca. 2000 extramatrical chlamydospores were distributed uniformly into the soil 
Table 1. Soil characteristics of the three Alfisol field locations

\begin{tabular}{|c|c|c|c|c|c|c|c|}
\hline \multirow[b]{2}{*}{ Location } & \multirow[b]{2}{*}{ Soil type } & \multirow[b]{2}{*}{$\begin{array}{l}\text { Total } \\
N(\text { (a) }\end{array}$} & \multirow{2}{*}{$\begin{array}{l}\text { NaHCO, } \\
\text { extractable } \\
\mathrm{P} \text { (ppm) }\end{array}$} & \multirow[b]{2}{*}{$\mathrm{pH}$} & \multicolumn{3}{|c|}{ VAM flora } \\
\hline & & & & & $\begin{array}{l}\text { Previuus } \\
\text { crop }\end{array}$ & Gencra ${ }^{*}$ & $\begin{array}{l}\text { Spores } / \\
25 \mathrm{ml} \text { soil }\end{array}$ \\
\hline$\widehat{A}$ & Alfisol & 0.03 & 3.5 & 6.2 & Fallow & G. Gig, A. Sc & 105 \\
\hline \multirow[t]{2}{*}{ B } & Alfisol & 0.04 & 5.0 & 6.7 & $\begin{array}{l}\text { Arachis } \\
\text { hyporgaca }\end{array}$ & G. Gis. A. Sc & 263 \\
\hline & Aliiksol & 0.07 & 20.0 & 7.0 & $\begin{array}{l}\text { Arachis } \\
\text { hyposaca }\end{array}$ & (i, Gig, A, Sc & 560 \\
\hline
\end{tabular}

${ }^{*} C=$ Cilomus: (iig $=$ (iiguspora; $A=$ Acaulospora: $S c=$ Sclerocystis

meant for each pot by mixing in a sealed plastic hap. Spore washings were given to the uninocu. ited control treatments. Plants were grow'n in alfisol soil, partially sterilized by steaming or $t \mathrm{~h}$ in a $\mathrm{l}$ indig soil sterilizing apparatus or non-sterilized. in $20 \mathrm{sm}$ pots filled with $5 \mathrm{~kg}$ soil. Three seeds were centrally sown and two wecks later seedlings were thinned to one per pot. $\mathrm{P}(\mathrm{t}$ ts were weighed and watered tegulurly to 80 \% of the ficld capacity. Nitrogen, as urea, at the rate of $60 \mathrm{~kg} \mathrm{~N} / \mathrm{ha}(275 \mathrm{mg}$ urea/pot) and phosphorus, as triple super phosphate, at the rate of $5 \mathrm{kf} \mathrm{P} / \mathrm{ha}$ (175 mf triple super phosphate/pot) was incorporated into the soil, prior to sowing. The experiments were conducted in a glasshouse with temperatures ranging from 26 to $35 \mathrm{c}$. Pots were arranged on tables as randomized hlocks. The position of the replicates was rotated every week among the benches in the glasshouse to reduce any positional effects within the glasshouse. Shont and root dry weights were recorded after drying in a hot-air oven at 60()$^{\circ}$ for $72 \mathrm{~h}$.

Roots from each plant were washed free of adhering soil on a sieve, and cut into $3 \mathrm{~cm} s e g$. ments and mixed thoroughly. Tour sub-samples cuntaining hetween $3-5 \mathrm{~g}$ roots were removed. pooled. and transferred into bottles, $10 \% \mathrm{KOH}$ added and the tissuc cleared by steuming in a stean sterilizer at $100 \mathrm{C}^{\circ}$ for $5 \mathrm{~min}$. I olluwed by staining with $0.08 \%$ trypan blue'". The percentage VAM colonization, the total mycorrhizal root length and the total ront length were estimated using a grid-line intersect method ${ }^{20}$. Phosphorus in the plant tissue was estimated according to Jackson'", nitrogen by the macro-Kjeladhal inethod ${ }^{3}$ and the mycorrhizal dependencies were calculated according to the method of Menge. Johnsun and Platt ${ }^{15}$,

Parent.progeny comparison. We compared the VAM colonization of two sclected male terile (female parent) lines (5141A and $111 \mathrm{~A}$ ), $5 \mathrm{R}$ lines (restorer lines, the male parents) nd their derived crosses. Plants were grown in an alfisol soil, with pH 6.0 and $4.0 \mathrm{ppm}$ NaHCO xtractable $P$ : and they were harvested 60 days after planting. Pots were artanged in a ran. lomized block design with 3 replications.

Growth response variation. The second pot experiment used ten pearl millet genotypes selected from the 30 used in the ficld trials to examinc if genotypes varied with respect to VAM colonization and whether they responded to inoculation. For each genotype, there were 3 treatments: 1) uninoculated control in sterilized soil, 2) inoculated with (Gigasporo calospora cloned from a single spore isolate, and 3 ) non-sterilized soll representing the natural VAM fora. The soil had a $\mathrm{pH}$ of 6.0 and contained $1.5 \mathrm{ppm} \mathrm{NaHCO}$ extractable phosphorus. Plants were harvested 60 days after planting. Pots were arranged in a randomized block design with 6 replications.

Another pot trial examined the responsc of threc West African pearl millet lines for dry matter, and phosphorus uptakc. Gigaspora calospara was inoculated in both sterilized and nonsterilized alfisol soil and pots without inoculation served as control. The soil had a $\mathrm{pH}$ of 6.8 and contained $4.5 \mathrm{ppm} \mathrm{NaHCO}$ extractable P, and VAM fungi of the genera Glomus, Gigaspora. Acaulospora and Sclerocystis, at a total population of 135 spores per $150 \mathrm{ml}$ soil. Pots were arranged in a randomized block design with 4 replications. 


\section{Results}

The 3 field trials aimed to study the variation between 30 genotypes of pearl millet to mycorrhizal colonization by the indigenous VAM fungi. The mean mycorrhizal colonization of the genotypes, across locations, varied between 26 and $57 \%$ (Table 2). The ranges of percentage VAM root colonization for locations A, B and C were 13 to 44,10 to 59 and 35 to 77 respectively. Overall, the genotypes tended to show similar rankings for VAM colonization. Genotype times location interaction was highly significant $(P \leqslant 0.01)$.

In the first pot experiment the male sterile (MS) line, 5141A was more colonized by VAM than the other MS line. $111 \mathrm{~A}$ (Table 3). Tws crosses made using $111 \mathrm{~A}$ as female parent and $631 \mathrm{P}-3$ and $733 \mathrm{P}$ as male parents resulted in hybrids with more VAM colonization that either of the two parents. A cross between 5141A and 623 P.2 resultec in Fl progeny which had less VAM colonization than either of the parent lines. Colonization of many other crosses derived using different male parent lines was not affected. A single representation of this group (612P-1) has been shown in Table 3.

The relation between root growth (total root length). the total mycorrhizal root length, the percentage VAM colonization of the ten genotypes, and the growth and $\mathrm{P}$ uptake response to inoculation were determined in another pot trial with 10 genotypes. Analysis of variance revealed that the genotypes varied significantly $(P \leqslant 0.05)$ in VAM colonization by a single inoculum strain and also when grown in nonsterilized soil containing several indigenous VAM fungal species (Table 4). The total root length of the 10 genotypes grown in sterilized soil with Gigaspora calospora was statistically similar, but the total length of mycorrhiza in the roots (mycorrhizal root length) varied significantly $(P \leqslant 0.05)$ between genotypes. Similarly, under the unsterilize condition, a group of genotypes (IP 5140. IP 4937 and MBH 11 ( recorded different amounts of total mycorrhizal root length.

Total root length and the level of mycorrhizal colonization varied hetween cultivars (Table 4 ). Generally root growth was doubled by the presence of VAM, presumably because of the better plant nutrition. There was an interaction between cultivars and soil treatment with respect to VAM infection level. Most cultivars had similar lengths of infected root between treatments, but for cv IP 4937 more VAM development occurred in the non-sterilized inoculated soil than in the non-sterile soil. Total root length did not differ between soil treatments.

The plant growth (Plate 1) and dry-matter responses to mycorrhizal inoculation (Gigaspora calospora) of the 10 pearl millet genotypes 
Table 2. Genotype dependent variation in the mycorrhizal colonization of pearl millet grown at three different field locations with genotypes ranked according to overall means

\begin{tabular}{|c|c|c|c|c|c|}
\hline \multirow{2}{*}{$\begin{array}{c}\therefore \\
\text { Genotype }\end{array}$} & \multirow{2}{*}{$\begin{array}{l}\text { Country of } \\
\text { origin }\end{array}$} & \multicolumn{3}{|c|}{ VAM colunization $(\%$} & \multirow[b]{2}{*}{ Mean } \\
\hline & & Alfisol A & Alfisol B & Alfisol C & \\
\hline IP $327 ?$ & India & 15 & 11 & 51 & 25 \\
\hline IP 3476 & India & 13 & 20 & 49 & 27 \\
\hline IP 578 I & Nigeria & 16 & 32 & $3 \bar{y}$ & 29 \\
\hline IP 3595 & India & 22 & 10 & 56 & 30 \\
\hline IP 5150 & Niger & 24 & 30 & 35 & 30 \\
\hline IP 4382 & India & 15 & 22 & 56 & 31 \\
\hline IP 6891 & Tanzania & 25 & 32 & 40 & 32 \\
\hline IP 6045 & Niger & 21 & 33 & 41 & 32 \\
\hline IP 6114 & Cameroun & 25 & 28 & 49 & 34 \\
\hline IP 4807 & India & 23 & 28 & 57 & 36 \\
\hline IP 5427 & iviger & 26 & 27 & 56 & 36 \\
\hline IP $\$ 335$ & Niger & 22 & 33 & 55 & 37 \\
\hline WCer75 & India & 17 & 23 & 73 & 38 \\
\hline IP 6590) & Malawi & 3,3 & 40) & 42 & 38 \\
\hline If 6139 & Cumeroun & 28 & 35 & 53 & 39 \\
\hline IP 486] & Lebenon & 22 & 25 & 70 & 39 \\
\hline ICH $22 \dot{U}$ & India & 30 & 36 & 52 & 39 \\
\hline BJ 104 & India & 27 & 34 & 58 & 40 \\
\hline $\mathrm{MBH} 110$ & India & 23 & 30 & 67 & 40 \\
\hline IP 5420 & Niger & 15 & 42 & $6 \hat{2}$ & 40 \\
\hline IP 3840 & India & 27 & 42 & 52 & $4 i$ \\
\hline IP 3120 & India & 25 & 26 & 77 & 43 \\
\hline IP 5692 & Nigeria & 29 & 33 & 70 & 44 \\
\hline IP $\$ 306$ & Niger & 22 & 44 & 70 & 45 \\
\hline IP 5009 & Nigeria & 23 & 47 & 74 & 48 \\
\hline IP 5310 & Niger & 44 & 43 & 61 & 50 \\
\hline LP 4937 & Uganda & 30 & 50 & 66 & 48 \\
\hline IP 6538 & Mali & 33 & 41 & 74 & 50 \\
\hline IP $\$ 140$ & Niger & 37 & 49 & 77 & 54 \\
\hline \multirow[t]{5}{*}{ IP 5921} & Scnegal & 42 & 59 & 67 & 56 \\
\hline & SE (Genotypes) & \pm 3.1 & $: 4.4$ & +4.2 & \pm 2.1 \\
\hline & Mean & 26 & 34 & 57 & 39 \\
\hline & SE (Location) & & \pm 1.5 & & \\
\hline & CV $\%$ & 24 & 12 & 14 & 18 \\
\hline
\end{tabular}

Alfisol A - Low fertility; not cultivated previous two seasons; 3.5 ppin Olsen's $P$.

Alfisol B - Low fertility; cultivated previous season; 5.0 ppm Olsen's P.

Alfisol C - High fertility; under long term cultivation; $20.0 \mathrm{ppm}$ Olsen's $P$.

- each value is a mean of 20 observations made from each of 4 replicate plots of 2 rows and $3 \mathrm{~m}$ in length. 
1able 3. Mycorrhizal colonization of parent penotypes and some selected crosses of pearl millet grow'n in natural field soil under greenhouse condition

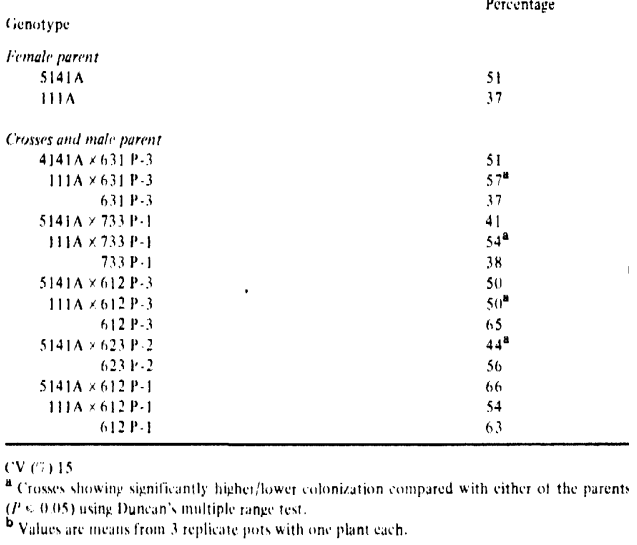

grown in sterilized soil varied significantly (Table 5). IP 5921 gave maximum response to inoculation and recorded very low dry matter without inycorrhiza. There was little difference hetween the growth of genotypes in sterilized soil with a single VAM isolate and the growth in non sterilized soil. ICH 220 and IP 4382 produced more plant dry matter after inoculation in sterilized soil, than in non-sterilized soil. Analysis of variance showed that phosphorus uptake of the ten geno. types inoculated with single VAM isolate in sterilized soil or due to indigenous VAM tlora in non-sterilized soil also differed significantly $(P \leqslant 0.05)$ (Table 5$)$. There was also a significant $(P \leqslant 0.05)$ difference between genotypes in $P$ uptake for all 3 inoculation regimes.

Total mycorrhizal root length and the percentage colonization were correlated $(P \leqslant 0.01 \mathrm{df} 28)$ with total root length, shoot and total plant dry matter, and total phosphorus uptake (Table 6). Root dry weight was not correlated with total mycorrhizal root length. The tissuc phosphorus concentration was not related to mycorrhizal colonization of roots. This is presumably because genotypes vary in their strategy for coping with low $\mathrm{P}$ availahility in the non-mycorrhizal state. 


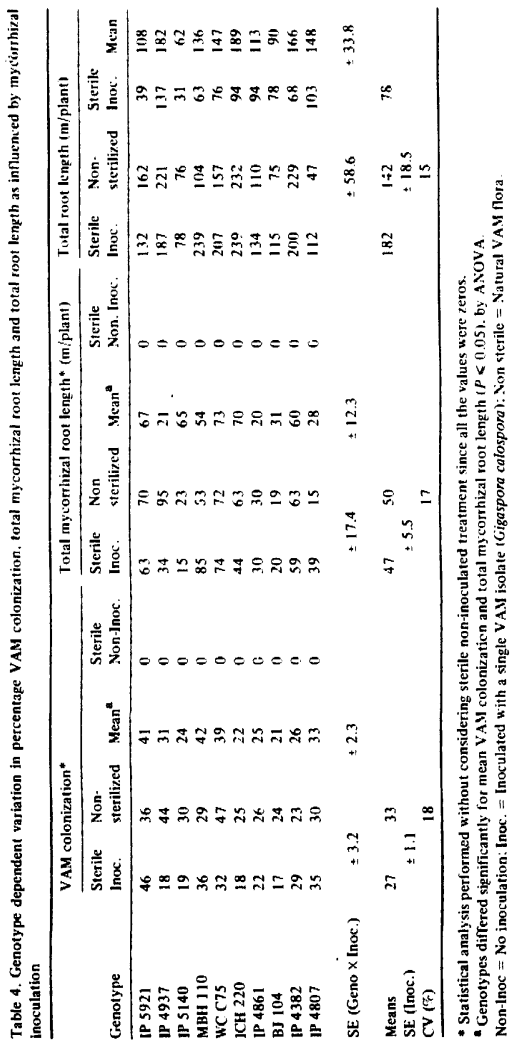




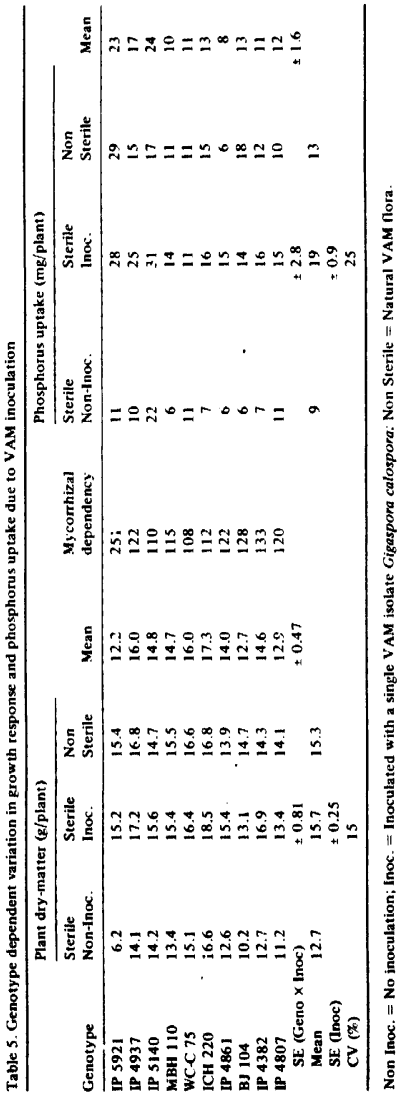



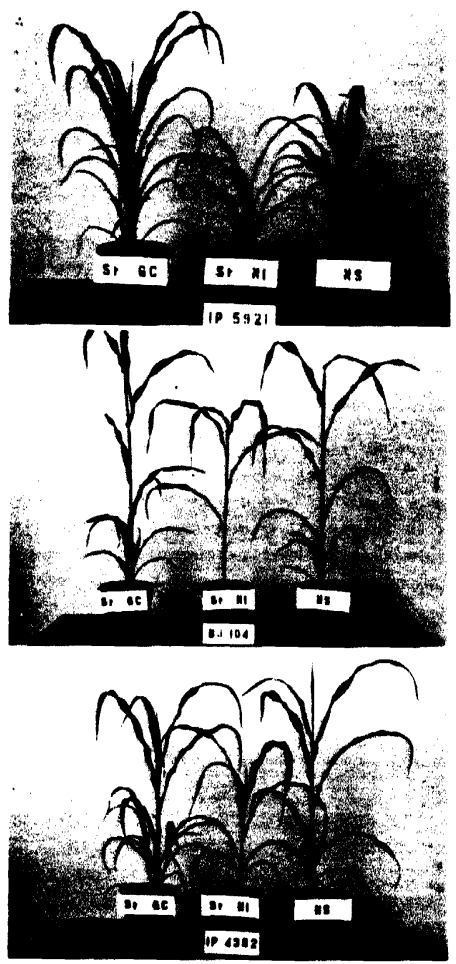

Phate 1. Three pearl millet genotypes showing differentlal response to inoculation with a single VAM isolate Gigaspora calospora (St Gc) indigenous VAM flora i.e. non-sterillzed soil (NS) compared with uninoculated control in sterilized soil (St NI). Note higher growth of IP 5921 when inoculated compared to naturally available VAM fungi. 
The response to inoculation with Gigaspora calospora resulted in significant $(P \leqslant 0.05)$ increase in dry matter and $P$ uptake by the two West African cultivars, IP 5921 and ZAN but the third cultivar SDL did not respond (Tabic 7). The cultivar ZAN produced most plant dry matter. and had the largest response to VAM inoculation in both sterilized and non-sterile soil. The cultivar IP 5921 also responded to inoculation in non-sterile soil. Cultivar ZAN was dependent on the presence of VAM for P uptake, and grew poorly without the VAM. In the non-sterile soil plant growth. however varied between inoculated and noninoculated treatments even though they had the same level of mycorrhizal colonization, suggesting that $G_{\text {. calospora was }}$ more competitive and efficient fungus that the strains of the indigenous population. The other two cultivars were able to extract suft ficient P from the soil for reasonable plant growth in the absence of VAM.

\section{Discussion}

This study shows that the genotypes of pearl millet can support different amounts of mycorrhizal colonization when exposed to either a single VAM isolate or a mixture as found in the field or in nonsterilized soil in pots. Comparing host crop species. Mosse' ${ }^{17}$ reported that certain legune's showed greater levels of colonization than grasses. Root colonization levels vary a great deal hetwe'n plant species. For pearl millet genotypes grown in the same field colonization can vary from 25 to $56 \%$. Menge ${ }^{14}$ believes that rapid and high levels of colonization may be the prime determinant of the efficiency of the symhiosis. Thus, screening and selection of genotypes which allow rapid and high levels of colonization may be a factor to incorporate in crop breeding programs.

Huisman ${ }^{12}$ pointed out that percentage colonization. is often. if not always confounded by differential root growth rates between genotypes or species. Our study suggests that $34^{\prime} \%$ (Table 6) of the variation in percentage colonization of pearl millet can be attributed to variation in root length. However, for several genotypes with a similar root length there were large differences in the extent of VAM colonization. Genotype variation in root colonization and response to VAM could he due to an interaction between host genotype and VAM strain preferences ${ }^{17}$. The number of infection sites on the root could be a factor ${ }^{4,20}$. Different levels of colonization between genotypes could arise from differences in the rate of growth of the fungus through the root cortex ${ }^{20}$ and our present single harvest experiment 
Table 6. Correlation matrix showing relationships between VAM, plant growth and phosphorus uptake parameters (stcond pot experiment)

\begin{tabular}{lll}
\hline Parameter & Coefficient & \\
\hline & M Colonization & Mycorrihizal root length \\
Percentage colonization & 1.000 & \\
Total mycuirhizal root length & $0.991^{* *}$ & 1.00 \\
Total ront length & $0.584^{* *}$ & $0.640^{* *}$ \\
Shoot dry weight & $0.500^{* *}$ & $0.520^{* *}$ \\
Root dry weight & $0.331^{*}$ & 0.250 \\
Plant dry weight & $0.560^{* *}$ & $0.585^{* *}$ \\
Percentage P in tissue & 0.170 & 0.207 \\
Total phosphorus uptake & $0.444^{*}$ & $0.460^{* *}$ \\
\hline
\end{tabular}

Significance: $* P<0.05, * * P<0.05$.

Table 7. Intluence of mycorrhizal inoculation on the growth and phosphorus uptake of three West Afritan pearl millet genotypes

\begin{tabular}{|c|c|c|c|c|c|c|c|}
\hline \multirow[b]{2}{*}{ Soil } & \multirow[b]{2}{*}{ Genotype } & \multicolumn{2}{|c|}{$\begin{array}{l}\text { Shoot dry weight } \\
\text { (k/plant) }\end{array}$} & \multicolumn{2}{|c|}{$\begin{array}{l}\text { Phosphorus uptake } \\
\text { (mg/plant) }\end{array}$} & \multicolumn{2}{|c|}{$\begin{array}{l}\text { VAM colonization } \\
(x)\end{array}$} \\
\hline & & M & NM & M & NM & M & NM \\
\hline Sterilized & $\begin{array}{l}\text { IP } 5921 \\
\text { SI)L } \\
\text { ZAN }\end{array}$ & $\begin{array}{l}6.91 \\
4.96 \\
7.83\end{array}$ & $\begin{array}{l}4.74 \\
4.20 \\
2.93\end{array}$ & $\begin{array}{l}16.3 \\
16.3 \\
19.3\end{array}$ & $\begin{array}{r}13.0 \\
13.8 \\
8.3\end{array}$ & $\begin{array}{l}48^{\mathrm{c}} \\
14^{\mathrm{a}} \\
31^{\mathrm{b}}\end{array}$ & $\begin{array}{l}0 \\
0 \\
0\end{array}$ \\
\hline Non-sterilized & $\begin{array}{l}\text { IP 5921 } \\
\text { SDL } \\
\text { ZAN }\end{array}$ & $\begin{array}{l}5.23 \\
4.91 \\
5.47\end{array}$ & $\begin{array}{l}4.73 \\
3.92 \\
4.03\end{array}$ & $\begin{array}{l}15.2 \\
11.7 \\
12.7\end{array}$ & $\begin{array}{l}14.3 \\
10.2 \\
11.0\end{array}$ & $\begin{array}{l}78^{\mathrm{d}} \\
46^{\mathrm{bc}} \\
53^{\mathrm{cd}}\end{array}$ & $\begin{array}{l}44^{\mathrm{bc}} \\
35^{\mathrm{bc}} \\
52^{\mathrm{cc}}\end{array}$ \\
\hline \multicolumn{2}{|c|}{ SF: (Genotype $\times$ inoculation) } & \multicolumn{2}{|c|}{ \pm 0.334} & $15.25^{ \pm}$ & \pm 0.81 & & \\
\hline St (inoculation) & & & & & & \multicolumn{2}{|c|}{10} \\
\hline
\end{tabular}

Fach value is a mean of 8 observations.

IP $5921=$ Germplasm line from Senegal $:$ SDL $=$ Sadore local $Z$ AN $=$ Zanfarwa .

$M=$ Inoculated with mycorrhiza - (igaspora calospora; $N M=$ Non inoculated.

For VAM colonization, values with similar superscripts are not significantly different at $P<$ 0.05 ; analysed after $\log (x+1)$ transformation.

cannot differentiate between the two factors. The latter would be partly related to the balance of inhibitory substances produced in response to the infection such as phenolics, phytoalexins, and promoting substances such as carbohydrates. Root tissue $\mathrm{R}$ concentration may also affect the rate of colonization ${ }^{16}$.

The VAM colonization level varied between location increasing with VAM spore populations in the soil and soil P level. However, the differences in colonization could also be due to strain variation between sites within the VAM soil inoculum. The location with the 
greatest level of VAM colonization had been in continuous cultivation for the past 8 years, given high rates of $\mathrm{N}$ and $\mathrm{P}$ fertilizer, with rotation between crops of sorghum, groundnut and pearl millet. The pearl millet genotypes grew most rapidly at this site and presumably soluble carbohydrate levels in the roots were also greatest.

The plant growth response to VAM inoculation was also genotype dependent. For example the genotype ZAN, had a large response to inoculation in both sterilized and non-sterile soil. Cultivars of wheat have differed in the dry-matter response to VAM inoculation ${ }^{1}$. There were differences between genotypes in their response to VAM colonization some heing much more dependent than others on the VAM (Table 5). The cultivar WC C 75 was unique with no effect of the VAM on plant growth or $\mathbf{P}$ uptake.

While there was a significant correlation between the extent of mycorrhizal root length and plant dry weight. this accounted for only $34 \%$ (Table 6) of the variation in plant dry weight. Mycorrhizal infection can affect the biochemical and physiological activities of plants $^{6.9}$, and this response is likely to be genotype dependent. Pearl millet showed differences between genotypes in P uptake in response to VAM infection. Thus the VAM activity with regard to $P$ uptake and translocation may be under the control of host genetic constitution and the physiological need for this element. A VAM fungus identified as highly efficient for $P$ uptake on one host, perhaps even a genotype within a crop species, may not perform efficiently when tested on another host.

The differences in percentage VAM colonization between parents and progenies suggests that it is a heritable trait and therefore the possibility to breed for increased mycorrhizal colonization exists.

Acknowledgements We thank Drs Sarah Sinith. Melvin Daft and Francis Bidinger for com. ments on the manuscript, Drs S Appa Rao and B S Talukdat for seed material and Ms R Mohan and $\mathrm{K}$ G Papavinasa Sundaram for excellent technical help.

\section{References}

1 Azcon $R$ and Ocampo N A 1980 Factors affecting the vesicular arbuscular infection and mycorrhizal dependency of thirteen wheat cultivars. New Phytol. 87,677-685.

2 Bertheau Y, Gianinazzi-Pearson V and Gianinazzi S 1980 Development et expression de l'association endomycorrhizjenne chez le ble I. Mise en evidence d'un effet varietal. ann. Amelior. Plantes. 30, 67-78.

3 Bremner J M 1965 Total Nitrogen. In Methods of Suil Analysis (Part 2). Ed. C A Black. Amer. Soc. Agron. Madison, Wisc. pp 1149-1179. 
4 Buwalda J G. Ross G J S. Stribley D P and Tinker P B 1982 The development of endomycorrhizal root systems IV. The mathematical analysis of effects of phosphorus on the spread of vesicular-arbusculat mycorthizal infection in root systems. New Phytol, 92, $391-399$.

5 Carliny D E and Brown M F 1980 Relative effects of vesiculas arbuscular mycorrhizal fungus on the growth and yield of soybeans. Soil Sci. Soc. of Am. J. 44, 528-532.

6 Carling D E and Brown M F 1982 Aratomy and physiology of vesicularerbuscular and non-mycorrhizal roots. Phytopathol. 72, 1108-1114.

7 Clark R B 1983 Plant genotype differences in the uptake, translocation, accumulation and use of minesal elements required for plant growth. Plant and Soil 72,175-196.

8 Clark R B. Maranville J W and Gorz H J 1978 Phosphorus efficiency of sorghum grown in limited phosphorus. In Proccedings of the 8th International Colloquim on Plant Analysis and Fertilizer Problems. Eds. A R Ferguson, R L Bieleski and I B Fergusun. pp 93-99. Auckland, New Zealand.

9 Gianinazzi-Pearson V and Gianinazzi S 1983 The physiology of vesiculararbuscular 1 mycorrhizal roots. Plant and Soil 71, 197-209.

10 Giovanneti $M$ and Mosse B 1980 An evaluation of techniques for measuring vesicular arbuscular mycorrhizal infection in roots. New Phytol. 84, 489-500.

11 Hayman D S 1983 'The physiology of vesicular-arbuscular endomycorrhizal symbiosis. Can. J. Bot. 61, 944-963.

12 Huismann O C 1982 Interrelations of root growth dynamics to epidemiology of root invading fungi. Ann. Rev. Phytopathol. 20, 303-327.

13 Jackson M L 1971 Soll Chemical Analysis. pp 574, Prentice Hall of India (Ltd). New Delhi.

14 Menge J A 1983 Utilization of vesicular arbuscular mycorrhizal fungl in agriculture. Can. J. Bot. 61, 1015-1024.

15 Menge J A, Johnson E L V and Platt R G 1978 Mycorrhizal dependencey of several citrus cultivars under three nutrient regimes. New Phytol. 81, 553-559.

16 Menge J A. Steirle O. Bagyaraj D J, Johnson E L V and Leonard R T 1978 Phosphorus concentrations in plants responsible for inhibition of mycorrhizal infection. New Phytol $80,575-578$.

17 Mosse B 1980 Vesicular-arbusular mycorrhiza research for Tropical Agriculture. Research Bulletin. Hawaii Institute of Tropical Agriculture and Humun Resources 194, 14-15.

18 Phillips J M and Hayman D S 1970 Improved procedures for clearing and staining parasitic and vesicular arbuscular mycorthizal fungi for rapid assessment of infection. Trans. Br. Mycol. Soc. 55, 158-160.

Powell C L and Sithamparanathan J 1977 Mycorrhizas in Hill Country soils. IV. Infection rate in grass and legumes species by indigenous mycorrhizal fungi field conditions. N.Z.J. Agric. Res. 20,489-502.

20 Smith S E and Walker N A 1981 A quantitative study of the mycorrhizal infection in Trifolium; separate determination of the rates of inefection and of mycelial growth. New Phytol. 89, 225-240. 